\title{
Elemental composition of seeds of representatives of the genus Turbinicarpus (Backeb.) Buxb. et Backeb.
}

\section{Tatsiana Shlapakova}

Central Botanical Garden of the National Academy of Sciences of Belarus, Surganov street 2v, 220012, Minsk, Republic of Belarus

E-mail:T.Shlapakova@cbg.org.by

\begin{abstract}
The article presents data on the elemental composition of seeds of species of the genus Turbinicarpus. The study of the content of chemical elements in seeds makes it possible to explain their species-specificity, which can be used as one of the systematic characteristics of the studied group of plants.
\end{abstract}

Keywords: Chemical elements, scanning electron microscopy

\section{Introduction}

Electron microscopy with electron probe chemical analysis makes it possible to find out the elemental composition of seeds of the studied species and to carry out their quantitative analysis. In works Sorokopudov (Sorokopudov et al., 2012) and Tokhtar (Tokhtar et al., 2012) differences in the percentage of individual chemical elements in different parts of fruits and seeds were found. Belopukhov (Belopukhov et al., 2012) divided chemical elements into groups depending on their percentage in plants, which also makes it possible to use this as a systematic trait.

Turbinicarpus (Backeb.) Buxb. et Backeb is a genus of Mexican cacti which, according to Hunt et al. (Hunt et al., 2006) includes 16 species and 21 subspecies; however, the number of species and subspecies varies among authors (Anderson, 2001; Donati and Zanovello, 2005). Turbinicarpus extends in the northeastern region of the Republic of Mexico (in the Sonoran and Highland Mexican provinces of the Holarctic Kingdom (northeastern regions of Mexico, in particular, the states of San Luis Potosi, Guanajuato, Nuevo Leon, Queretaro, Hidalgo, Coahuila, Tamaulipas, and Sac). Due to illegal harvesting, changes in soil use, and overgrazing, all species of the genus, except for T. horripilus, are listed in NOM-059-SEMARNAT 2010. In addition, all species of this genus are included 
in Appendix I of CITES (Hunt et al., 2016) and the Red List of the International Union for Conservation of Nature (Duarte et al., 2015).

Turbinicarpus have a spherical or slightly flattened stem that varies in color from grayish to brown (Figure 1). The height and diameter of representatives of this genus vary from $1.5 \mathrm{~cm}$ to $12-14 \mathrm{~cm}$. The ribs are divided into tubercles. The tubercles are pronounced, rounded, located in a spiral. The spines are usually in the form of papery, hair-like, or feathery structures. Areolae are covered with white hairs. Plants have a turnip root, which accumulates not only moisture but also nutrients, it penetrates very deeply into the substrate and becomes thinner to the lower part. The flower is sessile, $0.7-3.8 \mathrm{~cm}$ long. The color of the perianth varies by species and subspecies and can be white, yellow, red, pink, or purple. Numerous stamens grow together with the perianth. Ripe fruits are $0.4-1.8 \mathrm{~cm}$ long, berry-like, and fleshy. Seeds are 1-1.5 mm long, black or red (Mario, 2004).
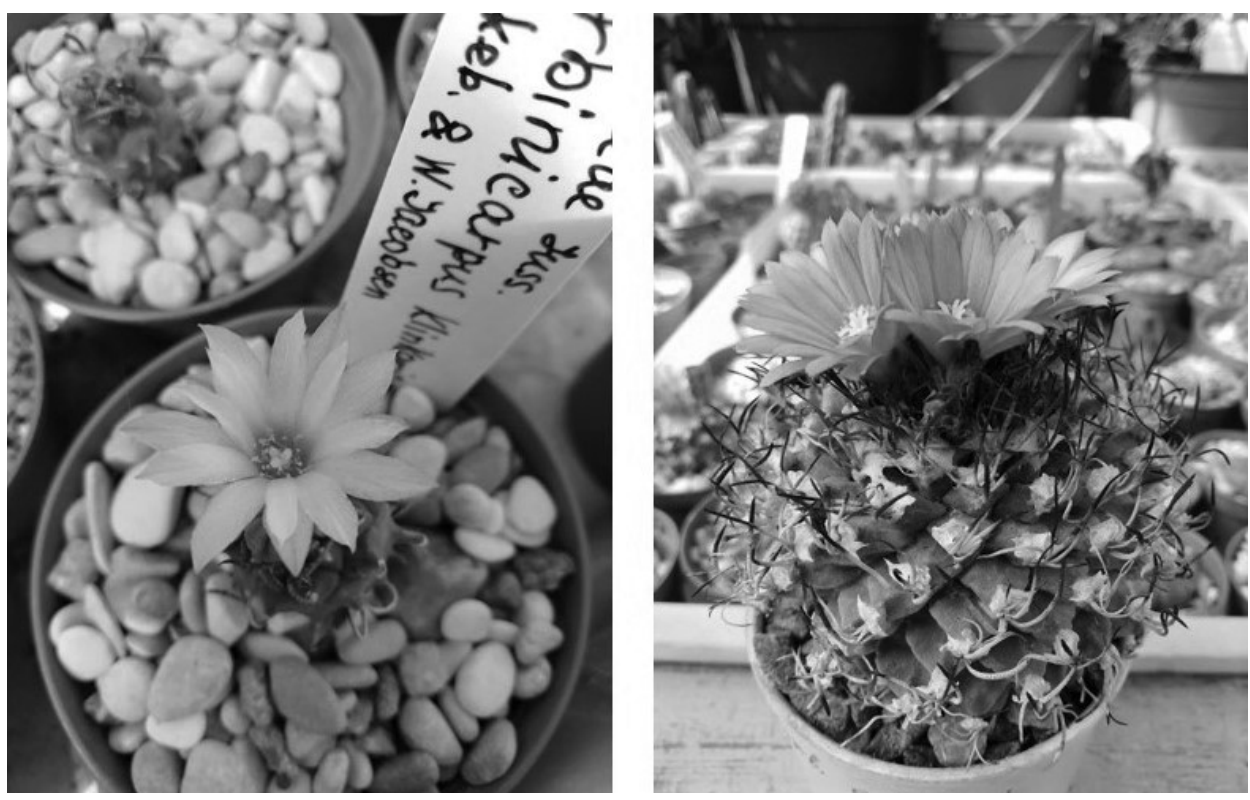

Figure 1. T. schmiedickeanus subsp. klinkerianus (Backeb. \& W. Jacobsen) Glass \& R. A. Foster and T. alonsoi Glass \& S. Arias.

Thus, the study of all aspects of the growth of this plant will lead to a more specific plan for conservation and restoration in habitats and botanical gardens. One of these aspects is the study of the structure and composition of seeds. The study aims to establish the elemental composition of seeds of the genus Turbinicarpus. 


\section{Materials and methods}

The objects of the study were seeds of 43 species of the genus Turbinicarpus. These are seeds of own reproduction of the Central Botanical Garden of the National Academy of Sciences of Belarus, as well as attracted seed material. The studies were carried out by scanning electron microscopy with electron probe chemical analysis using a JSM-5610 LV scanning electron microscope with an EDX JED-2201 chemical analysis system.

\section{Results and discussion}

The study established the mass fractions (\%) of the following chemical elements: $\mathrm{Na}, \mathrm{P}, \mathrm{Cl}, \mathrm{S}, \mathrm{Si}, \mathrm{Al}, \mathrm{Ca}, \mathrm{Mg}, \mathrm{K}$ (Table 1).

Table 1. Weight fraction (\%) of chemical elements in seeds Turbinicarpus

\begin{tabular}{|c|c|c|c|c|c|c|c|c|c|}
\hline Species (adopted names) & $\mathrm{Na}$ & Mg & Al & Si & $\mathbf{P}$ & $S$ & $\mathrm{Cl}$ & K & $\mathrm{Ca}$ \\
\hline $\begin{array}{l}\text { T. schmiedickeanus subsp. } \\
\text { klinkerianus (Backeb. \& W. } \\
\text { Jacobsen) Glass \& R. A. Foster }\end{array}$ & 0.65 & 1.29 & 0.84 & 0.59 & 0.08 & 0.62 & 0.99 & 8.40 & 1.55 \\
\hline T. klinkerianus "lilinkeuiduus" & 0.59 & 0.63 & 0.95 & 0.87 & 0.2 & 0.56 & 0.33 & 5.39 & 3.77 \\
\hline $\begin{array}{l}\text { T. lophophoroides (Werderm.) } \\
\text { Buxb. \& Backeb. }\end{array}$ & 0.24 & 1.5 & 1.11 & 0.29 & 0.47 & 0.58 & 0.31 & 6.75 & 2.51 \\
\hline $\begin{array}{l}\text { T. lophophoroides } \\
\text { f. roseiflorus }\end{array}$ & 0.55 & 3.34 & 0.71 & 3.68 & 0.34 & 0.37 & 0.45 & 10.12 & 2.82 \\
\hline $\begin{array}{l}\text { T. pseudomacrochele subsp. } \\
\text { lausseri (Diers \& G. Frank) } \\
\text { Glass }\end{array}$ & - & 0.65 & 0.78 & 0.31 & 0.23 & 0.19 & 0.08 & 7.48 & 2.36 \\
\hline $\begin{array}{l}\text { T. schmiedickeanus subsp. } \\
\text { andersonii Mosco }\end{array}$ & 1.01 & 0.82 & 0.81 & 0.4 & 0.01 & 0.20 & 0.06 & 2.2 & 2.62 \\
\hline $\begin{array}{l}\text { T. schmiedickeanus subsp. } \\
\text { flaviflorus (G. Frank \& } \\
\text { A.B. Lau) Glass \& R. A. Foster }\end{array}$ & 0.62 & 0.35 & 0.18 & 0.39 & 0.15 & 0.23 & 0.47 & 4.35 & 1.91 \\
\hline T. graminispinus Matusz. & - & 2.7 & 2.6 & 0.38 & - & 0.33 & 0.01 & 3.03 & 5.86 \\
\hline T. hoferi Lüthy \& A. B. Lau & 0.44 & 0.90 & 0.19 & 0.34 & 0.23 & 0.15 & 0.11 & 2.95 & 2.56 \\
\hline T. jauernigii G. Frank & 0.41 & 1.29 & 0.80 & 0.51 & 0.44 & 0.45 & 0.21 & 4.82 & 2.77 \\
\hline $\begin{array}{l}\text { T. pseudopectinatus } \\
\text { v. albiflorus }\end{array}$ & - & 0.54 & 0.78 & 1.25 & 0.19 & 0.42 & 2.31 & 6.25 & 2.04 \\
\hline
\end{tabular}




\begin{tabular}{|c|c|c|c|c|c|c|c|c|c|}
\hline Species (adopted names) & $\mathrm{Na}$ & $\mathrm{Mg}$ & Al & Si & $\mathbf{P}$ & $S$ & $\mathrm{Cl}$ & K & $\mathrm{Ca}$ \\
\hline $\begin{array}{l}\text { T. pseudopectinatus } \\
\text { v. rubriflorus }\end{array}$ & .99 & 0.40 & 1.82 & 0.80 & 0.10 & 0.48 & 0.54 & 3.63 & 2.76 \\
\hline $\begin{array}{l}\text { T. valdezianus (Møller) Glass } \\
\text { \& R. A. Foster }\end{array}$ & 0.37 & 0.07 & 1.91 & 2.32 & 0.05 & 0.80 & 0.36 & 10.3 & 2.88 \\
\hline T. valdezianus v. albiflorus & .12 & .36 & 2.34 & 0.62 & - & 0.64 & .62 & 15.16 & 2.72 \\
\hline $\begin{array}{l}\text { T. zaragozae (Glass \& } \\
\text { R. A. Foster) Glass \& Hofer }\end{array}$ & 2.67 & 0.49 & 1.34 & 2.88 & 0.38 & 0.27 & 0.34 & 4.62 & 6.36 \\
\hline $\begin{array}{l}\text { T. schmiedickeanus subsp. } \\
\text { bonatzii (G. Frank) Panar. }\end{array}$ & - & 0.74 & 2.24 & 1.59 & 0.37 & - & 0.31 & 6.57 & 1.50 \\
\hline T. schwarzii (Shurly) Backeb. & 0.10 & .20 & 0.88 & - & 0.03 & 0.04 & .19 & 9.96 & 1.50 \\
\hline $\begin{array}{l}\text { T. schwarzii v. rubriflorus } \\
\text { Gerhart Frank }\end{array}$ & 0.17 & 1.24 & 0.70 & 0.63 & 0.05 & 0.37 & 0.22 & 5.53 & 2.05 \\
\hline T. spacellatus & 0.38 & 0.53 & 0.78 & 1.45 & 0.43 & 0.45 & 0.42 & 2.97 & 7.43 \\
\hline T. $\times$ mombergeri Riha & 0.93 & 6 & 0.93 & .46 & 0.27 & .23 & 0.78 & 5.64 & 2.29 \\
\hline $\begin{array}{l}\text { T. gielsdorfianus (Werderm.) } \\
\text { John \& Riha }\end{array}$ & 0.38 & 0.8 & 0.84 & 0.15 & 0.11 & 0.29 & 0.22 & 3.96 & 2.64 \\
\hline $\begin{array}{l}\text { T. schmiedickeanus subsp. } \\
\text { gracilis (Glass \& R. A. Foster) } \\
\text { Glass. }\end{array}$ & 0.18 & 0.39 & 1.68 & 0.58 & 0.38 & 0.16 & 0.17 & 5.86 & 3.71 \\
\hline $\begin{array}{l}\text { T. saueri subsp. } \\
\text { knuthianus (Boed.) Lüthy }\end{array}$ & 0.11 & 0.77 & 1.86 & 0.64 & 0.68 & 0.22 & 0.79 & 5.26 & 1.54 \\
\hline $\begin{array}{l}\text { T. pseudomacrochele subsp. } \\
\text { minimus (G. Frank) Lüthy \& } \\
\text { A. Hofer }\end{array}$ & 0.32 & 0.73 & 1.07 & 2.7 & 0.57 & 0.28 & 0.14 & 2.67 & 1.13 \\
\hline T. krainzianus v. lausseri & 0.33 & .19 & 1.48 & .22 & 0.16 & 0.35 & 0.28 & 4.71 & 0.96 \\
\hline $\begin{array}{l}\text { T. schmiedickeanus subsp. } \\
\text { macrochele (Werderm.) } \\
\text { N.P. Taylor }\end{array}$ & 0.91 & 0.79 & 0.54 & 0.17 & 0.23 & 0.39 & 0.64 & 5.19 & 1.14 \\
\hline T. macrochele v. kupackii & 0.46 & 0.86 & 0.58 & 0.59 & 0.28 & 0.16 & 0.42 & 6.37 & 1.69 \\
\hline T. macrochele v. frail & 1.1 & 0.38 & 0.76 & 0.69 & 0.10 & 0.12 & 0.13 & 5.81 & 1.47 \\
\hline T. polaskii Backeb. & 2.1 & 1.5 & 0.85 & 0.24 & 0.87 & 0.47 & 0.51 & 9.48 & 1.79 \\
\hline $\begin{array}{l}\text { T. pseudomacrochele } \\
\text { (Backeb.) Buxb. \& Backeb. }\end{array}$ & 0.06 & 0.65 & 0.84 & 1.31 & 0.46 & 0.29 & 0.47 & 4.58 & 1.52 \\
\hline $\begin{array}{l}\text { T. pseudomacrochele } \\
\text { v. alenae }\end{array}$ & 0.05 & 0.66 & 0.63 & 1.02 & 0.18 & 0.03 & 0.14 & 5.67 & 1.39 \\
\hline
\end{tabular}




\begin{tabular}{|c|c|c|c|c|c|c|c|c|c|}
\hline Species (adopted names) & $\mathrm{Na}$ & Mg & Al & Si & $P$ & $S$ & $\mathrm{Cl}$ & K & $\mathrm{Ca}$ \\
\hline $\begin{array}{l}\text { T. schmiedickeanus subsp. } \\
\text { dickisoniae (Glass \& R. A. } \\
\text { Foster) N. P. Taylor }\end{array}$ & 1.13 & 0.99 & 1.83 & 0.83 & - & 0.48 & - & 4.79 & 1.65 \\
\hline T. swobodae Diers \& Esteves & 0.99 & 1.41 & 2.43 & 1.19 & - & 0.26 & 1.10 & 3.47 & 9.33 \\
\hline $\begin{array}{l}\text { T. saueri subsp. ysabelae } \\
\text { (Schlange) Lüthy. }\end{array}$ & 0.34 & 0.59 & 1.41 & 0.24 & 0.08 & 0.26 & - & 6.64 & 1.86 \\
\hline T. saueri (Boed.) John \& Riha & 2.38 & 1.57 & 0.97 & 0.85 & 0.12 & - & - & 6.69 & 2.54 \\
\hline T. saueri subsp. gonzalezii & 0.99 & 0.63 & 0.97 & 0.73 & 0.26 & 0.21 & - & 5.21 & 1.34 \\
\hline T. beguinii $v$. senilis $f$. nobile & 3.87 & 1.62 & 2.05 & 1.99 & 0.62 & 0.05 & 0.05 & 6.74 & 6.66 \\
\hline $\begin{array}{l}\text { T. mandragora (Frič ex A. } \\
\text { Berger) A. D. Zimmerman }\end{array}$ & 2.88 & 1.09 & 2.78 & 0.68 & - & 0.20 & 1.14 & 6.68 & 4.27 \\
\hline T. alonsoi Glass \& S. Arias & - & 2.13 & 1.76 & 1.16 & - & 0.54 & - & 10.29 & 2.05 \\
\hline T. laui Glass \& R. A. Foster & 0.58 & 2.34 & 1.35 & - & 0.81 & 0.59 & 0.41 & 7.38 & 3.75 \\
\hline T. roseiflorus Backeb. & 0.48 & 1.11 & 0.22 & 0.75 & 0.15 & 0.33 & 0.41 & 3.87 & 1.1 \\
\hline $\begin{array}{l}\text { T. dickisoniae (Glass \& R. A. } \\
\text { Foster) Glass \& A. Hofer }\end{array}$ & - & 0.82 & 0.82 & 0.99 & 0.19 & 0.6 & 0.3 & 2.66 & 3.74 \\
\hline $\begin{array}{l}\text { T. pseudopectinatus (Backeb.) } \\
\text { Glass \& R. A. Foster }\end{array}$ & 1.04 & 0.16 & 0.65 & 0.58 & 0.22 & 0.57 & 0.59 & 4.31 & 1.05 \\
\hline T. saueri subsp. nelissae & 1.62 & 1.71 & 0.27 & 1.21 & 0.39 & 0.7 & 0.12 & 7.93 & 2.2 \\
\hline
\end{tabular}

These elements can be divided into two groups according to their content: $1^{\text {st }}$ group $-2.5-15.2 \%(\mathrm{~K}, \mathrm{Ca})$ and $2^{\text {nd }}$ group $-0.01-2.5 \%(\mathrm{Na}, \mathrm{P}, \mathrm{Cl}, \mathrm{S}, \mathrm{Si}, \mathrm{Al}, \mathrm{Mg})$. However, it is worth noting the exceptions in these groups. Thus, the weight fraction of $\mathrm{Na}$ in T. beguinii v. senilis $f$. nobile $-3.87 \%$, T. mandragora $-2.88 \%$, T. zaragosae - 2.67\%; $\mathrm{Mg}$ in T. schwarzii - 3.2\%; $\mathrm{Al}$ in T. mandragora $-2.78 \%$; $\mathrm{Si}$ in T. zaragosae $-2.88 \%$; $\mathrm{Ca}$ in T. bonatzii $-1.5 \%$, T. knuthianus $-1.54 \%$, T. pseudopectinatus - 1.05\%, T. polaskii - 1.79\%, T. schmiedickeanus subsp. klinkerianus $-0.42 \%$, T. schwarzii $-1.5 \%$. The highest content was shown by Ca (0.42-9.33\%), K (2.66-15.16), Mg (0.7-3.2\%), P (0.01-0.87\%) - included in phytin the main source of inorganic phosphate in seeds. Calcium in the composition of pectates is part of the cell walls of plants, its presence is important for the normal functioning of membranes, and it is an activator of enzymes also. Potassium is a calcium antagonist, is part of the enzymes involved in the formation of ATP in the process of oxidative phosphorylation, in addition, many enzymes involved in protein synthesis require the presence of potassium. Magnesium supports the structure of ribosomes by binding RNA and protein, is part of chlorophyll, and 
is an activator of many enzymes. Phosphorus is involved in metabolism, cell division, reproduction, the transmission of hereditary properties, and other complex processes occurring in the plant.

The seeds are the units of plants with the most stable characteristics. Therefore, the chemical composition of the seeds can be one of the important characteristics of taxonomy. The activity of most enzymes depends on the content of activators and inhibitors in the cells, which are micro-and macroelements.

This study showed that even within the same genus, species have a different elemental composition of seeds, which indicates the species specificity of this indicator.

Thus, the seeds have a species-specific elemental composition, which can be used as one of the diagnostic features to establish the systematic position of plant seeds obtained from controversial sources.

\section{References}

Anderson, E. F. 2001. The Cactus Family. $1^{\text {st }}$ Edition. Timber Press, Incorporated, Portland, Or. 776 p.

Belopukhov, S. L., Zhevnerov, A. V., Kalabashkina, E. V., and Dmitrevskaya, I. I. 2012. Determination of the micronutrient composition of flax products. Butlerov Readings. 32: 72-75.

Donati, D., Zanovello, C. 2005. Knowing Understanding and Growing Turbinicarpus-Rapicactus. A trip across the mexican states of Coahuila, Guanajuato, Hidalgo, Nuevo Leon, Queretaro... Cactus Trentino Südtirol, Trento. 256 p.

Duarte, J., Vogliotti, A., Cartes, J., and Oliveira, M. 2015. The IUCN Red List of Threatened Species. The IUCN Red List of Threatened Species. 1: 1.

Hunt, D., Taylor, N. and International Cactaceae Systematics Group (eds.). 2006. The New Cactus Lexicon. dh Books, Milborne Port.

Hunt, D. R., K. Royal Botanic Gardens, International Organization for Succulent Plant Study, and Conference of the Parties to the Convention on International Trade in Endangered Species of Wild Fauna and Flora. 2016. C.I.T.E.S Cactaceae Checklist.

Mario, J. M. S. A. A. G. F. R. S. B. 2004. The Genus Turbinicarpus in San Luis Potosi. $1^{\text {st }}$ Edition. Cactus \& Co., Venegono Sup., Italy.

Sorokopudov, V. N., Aldoshkin, I. S., Kolesnikov, D. A., Shestopalova, N. N., and Rybitsky, S. M. 2012. Elemental composition of fruits and seeds of some species and varieties of viburnum in the south-west of the Central Russian Upland. Scientific Bulletin of Belgorod State University. Series: Natural Sciences.

Tokhtar, L. A., Sorokopudov, V. N., and Kolesnikov, D. A. 2012. Elemental Composition of Fruits And Seeds of Red Currant. Scientific Bulletin of Belgorod State University. Series: Medicine. Pharmacy. 